\title{
THE INTRODUCTION OF A GAMBLING TAX IN SOUTH AFRICA - WHAT ARE THE ODDS ON THE IMPLEMENTATION THEREOF?
}

\author{
Milton Segal* \\ University of Witwatersrand \\ Milton.segal@wits.ac.za
}

Received: July 2013

\author{
Warren Maroun" \\ University of Witwatersrand \\ Warren.maroun@wits.ac.za
}

Accepted: March 2014

\begin{abstract}
The South African Revenue Service has been exploring the possibility of implementing a form of taxation on gambling winnings since the Minister of Finance's Budget Speech in 2010. On a superficial level it seems a logical mechanism for broadening the tax base - a case of increasing the tax collected from those who can afford the luxury of gambling. There are, however, a number of unintended consequences that government does not seem to have considered. As a result, this article uses a detailed content analysis of the prior academic and professional tax literature to explore possible weaknesses/flaws of a tax on gambling winnings in South Africa. These include the administrative burden of such a tax, certain economic consequences of allowing gambling losses as a tax deduction and the possible social consequences thereof. These findings mean that the article provides a meaningful contribution by critically assessing the proposed tax with the aim of informing policy development and future quantitative studies on a tax on gambling winnings.
\end{abstract}

Keywords

South African tax system; taxation on gambling; unintended consequences; tax reforms

*Mr M Segal is a senior lecturer at the School of Accountancy, University of the Witwatersrand, South Africa.

\#Prof WJ Maroun is an associate professor at the School of Accountancy, University of the Witwatersrand, South Africa. 


\section{INTRODUCTION}

The current South African tax treatment of gambling winnings depends mainly on whether the taxpayer engages in gambling activities as a business (in the case of a professional gambler) or merely for recreational purposes (as a casual gambler), usually by reference to a 'profit-making scheme test' commonly applied by the courts. In the case of the former, receipts from gambling constitute 'gross income', and are subject to tax at the applicable rate for the respective category of the taxpayer (De Koker \& Williams, 2011). Where gambling does not constitute the carrying on of a trade, receipts are of a capital nature and are not subject to Income or Capital Gains Tax (CGT) (Koekemoer, Wilcocks, van Schalkwyk, Stiglingh \& de Swardt, 2011). (Strictly speaking, both 'income' and 'capital gains' taxes are levied in terms the Income Tax Act No. 58 of 1962 (The Act). In the interests of brevity the research distinguishes between taxes on receipts and accruals not of a capital nature (income tax) and capital gains tax.)

In 2011, Finance Minister Gordhan proposed that South Africa, like Australia and the United States of America (USA), introduce a separate tax on gambling. A suggested $15 \%$ on winnings (not included in taxable income) in excess of R25 000 was tabled (Gordhan, 2011). The tax would be applicable to all winnings, including those from the National Lottery, with the express intention that such a measure would 'discourage excessive gambling' (Gordhan, 2011: 32). Conflicting statements by Treasury and the absence of clear proposals have, however, led to uncertainty. Government referred to a R25000 'exclusion' in the 2011 Budget Speech, but a R50 000 'deduction' in the People's Guide to the Budget Speech (Gordhan, 2011). There was also no indication of whether or not the tax relief would be available to reduce the tax liability for each win; for each period of assessment; or simply as a once-off source of tax relief. Adding to this, during 2012, the Minister announced a proposed national tax for casinos at a rate of $1 \%$ of casinos' gross gambling revenue (Gordhan, 2012). In addition to the existing provincial gambling taxes, taxpayers (the gambling organisations) would be required to pay a $1 \%$ levy on gamblingbased turnover (Paulsen, 2013), this being the 'the total amount wagered by players' (Vorster, 2012). No mention was made of the withholding tax proposals tabled during 2011 (Gordhan, 2012). This begs the question: did government intend the levy to replace the withholding tax or would it, as a tax on gambling institutions, be applied in addition to the tax effectively borne by the individual gambler? The 2013 Budget Speech provided no clarity. Despite the fact that the 2012 Budget Speech referred to 1 April 2013 as the effective date for the proposed levy to be implemented, no amendments to the Act dealing with the taxation of gambling have been effected, and the 2013 Budget Speech was silent on the issue.

Whether the withholding tax or the levy (or both) is subsequently enacted, the result will mark a material shift in tax policy. Individual winnings are frequently treated as exempt capital gains (Koekemoer et al., 2013). From the perspective of the gambling industry, the additional $1 \%$ levy on gambling revenues by relevant service providers is likely to be quantitatively material for the fiscus and taxpayers (Vorster, 2012). Consequently, understanding the exact nature and extent of future tax treatment of gambling winnings and exploring the possible consequences of the currently uncertain tax structure are important.

The prior corporate governance literature provides a number of accounts of cases in which the promulgation of new laws and regulations gives rise to significant unintended consequences. Marriott (2010) and Farrar (2011), for example, explain how political and social agendas detract from purely fiscal objectives of tax legislation in Canada and Australasia respectively. These include difficulties in collecting the taxes, the mechanisms for taxpayers to disclose their 
winnings and a decrease in demand for gambling. In a South African context, Maroun, Turner and Sartorius (2011) explain how CGT - purportedly enacted to entrench notions of fairness in the South African tax system - is characterised by elements that are interpreted by certain stakeholders as innately unfair. This research continues with this line of thought by exploring the possible unintended consequences of the proposed taxes on gambling.

A detailed content analysis of the prior literature on the taxation of gambling in the USA and Australia is carried out to identify key arguments and counter-arguments in favour of the proposed tax, and the practical difficulties encountered when a similar tax structure was implemented in those jurisdictions. The absence of direct prior research on the existing taxation of gambling in South Africa, coupled with the uncertain tax position outlined above, means that the research follows an interpretive approach. It does not provide a quantitative assessment of the costs and benefits of the proposed 'models' for gambling tax in South Africa, but rather seeks to add to the existing debate on the tabled changes to local tax law. While this may be construed as a threat to validity and reliability in a positivist sense (Creswell, 2009), the normative and qualitative style sheds light on what is and should be happening when it comes to South Africa's tax structure, making an important contribution to fiscal transparency and accountability (see Humphrey, 2008; Ahrens, 2008). At the same time, the exploratory style provides the basis for subsequent research that might be quantitative in nature.

The remainder of this article is organised as follows: section 2 provides a brief frame of reference for the research. Section 3 outlines the taxation of winnings from gambling in Australia, the USA and South Africa. Section 4 briefly presents the arguments in favour of a withholding tax on gambling in South Africa. Section 5 discusses certain possible consequences of the proposed tax on gambling. Section 6 concludes and identifies areas for future research.

\section{THEORETICAL FRAMEWORK: UNINTENDED CONSEPUENCES OF REGULATORY DEVELOPMENTS}

The prior corporate governance literature provides numerous accounts of regulatory developments having unintended consequences. For example Vakkur, Mcaffee and Kipperman (2010) examine the impact of the Sarbanes Oxley Act (2002) (SOX), which was intended to improve the control environment at organisations and promote greater certainty in capital markets. Practically, the inflexible rules-based approach followed by SOX, coupled with sanctions for non-compliance, has led to a decline in the value of firms. Similarly, the introduction of quality inspections by the Public Company Accounting Oversight Board (PCAOB) aimed at improving the quality of external audit (PCAOB, 2007) has had unintended consequences for the quality of corporate reporting. Delays in completing the audit of financial statements has resulted in the release of preliminary results by companies before the completion of audit fieldwork, leading to a decline in the reliability of preliminary announcements (Bronson, Hogan, Johnson \& Ramesh, 2011). Each case highlights how reforms 'not well informed by and well-grounded' in 'professional practice and the wide array of factors' influencing and shaping regulatory domains 'run the risk of producing unintended and potentially dysfunctional consequences' (Humphrey, Kausar, Loft \& Woods, 2011). By analogy, the same may apply to tax-related developments.

For example, in conventional accounting parlance, transfer pricing is used to allocate revenue, costs and capital among divisions to ensure an optimal economic outcome (Drury, 2005; Botten, 
2009). 'Such representations of transfer pricing simultaneously acknowledge and occlude how it is deeply implicated in processes of wealth retentiveness that enable companies to avoid taxes and facilitate flight of capital' (Sikka and Willmott, 2010, p. 342). Globalisation and the proliferation of multinational corporations driven by profit motive has had the unintended effect of mobilising bona fide mechanisms for efficiently allocating resources to enable the avoidance of taxation even if contrary to societal interests (Sikka and Willmot, 2010; De Koker \& Williams, 2011). Resulting efforts to curb these anti-avoidance schemes have not been a complete success, frequently adding to the complexity of tax systems (see Olivier, 2007; Oosthuizen, 2010; De Koker \& Williams, 2011).

South Africa's system of capital gains tax (CGT) provides another example of how tax systems may be plagued by unintended consequences. Maroun et al. (2011) explain how CGT purportedly enacted to entrench notions of fairness in the South African tax system - is characterised by elements that are interpreted by certain stakeholders as innately unfair. CGT has gone some way to addressing notions of tax equity by taxing vast stores of previously exempt capital wealth accumulated by a rich minority (Maroun et al., 2011). The tax has, however, been criticised as a source of double taxation which discourages the realisation of capital assets at the most efficient times (Voster, 2000; Conda, 2006, Roberts, 2006). The unintended effects of frustrating capital formation (Auten \& Cordes, 1991), promoting antiavoidance schemes (De Koker \& Williams, 2011) and becoming unnecessarily complex and practically difficult to comply with (Olivier, 2007) have detracted from CGT's status as a legitimate example of tax reform. Compounding this is the concurrent functioning of estate duty tax.

South Africa's policy of levying both estate duty and capital gain taxes on the death of a taxpayer was never an intended policy outcome (De Jager, Parsons \& Roeleveld, 2013). The current tax treatment not only results in a disconnect between South African and international tax practice (see De Koker \& Williams, 2011), but in the double taxation of individuals contrary to the basic principles of tax fairness (De Jager et al., 2013; Vivian, 2006). As with CGT, allegations of unfairness, complications when applying the relevant legislation, and the high administrative burden (De Jager et al., 2013; De Koker \& Williams, 2011) are unexpected difficulties that all too often characterise complex tax systems. The same applies to primary sources of state revenue such as value-added tax (VAT), the pay-as-you-earn system and income tax, where the emergence of innovative anti-avoidance schemes (Koekemoer et al., 2013) and the growing complexity of commercial arrangements have led to the proliferation of complex rules and exceptions to the rules that do not always operate as intended (see Koekemoer et al., 2013; De Koker and Williams, 2011).

The aim of this literature review is not to provide a complete account of the dysfunctional aspects of the South African tax system. What is important to appreciate is that rarely are proposed regulatory developments free from unintended consequences. When it comes to tax reform in particular, how tax systems are supposed to function, their actual effects, and how they are perceived by taxpayers are seldom aligned (Farrar, 2011), a warning that may be equally relevant for the proposed tax on gambling winnings. 


\section{TAXATION OF WINNINGS FROM GAMBLING IN AUSTRALIA, THE USA AND SOUTH AFRICA}

The Australian Income Tax Assessment Act 38 of 1997 (the Australian Income Tax Act) states that 'assessable income' includes gross income derived directly or indirectly from all sources, except for certain exempt amounts (Woellner, Barkoczy, Murphy, Evans \& Murphy, 2011). It is generally accepted that the only way winnings from gambling will not be taxable is if they are of a capital nature (Kreiser \& Jowitt, 1993), which is likely to be the case unless the gambling activities constitute the carrying on of a business (Oosthuizen, 2010; Woellner et al., 2011). Where the gambling activity does not constitute a business, s 118-37(1) of the Australian Income Tax Act exempts winnings from gambling from capital taxes and does not allow the deduction of losses from gambling (Deutsch, Freizer, Fullerton, Gibson, Hanley \& Snape, 2005, Oosthuizen, 2010).

The USA, however, requires the inclusion of all gambling receipts into 'adjusted gross income', irrespective of whether the gambling activity constitutes the carrying on of a trade or business or not (Smith, 2002:446). The Inland Revenue Services (IRS) allows gambling losses to be deducted. Gambling gains are the 'full amount of winnings less the cost of placing the winning bet' (Blau \& Coutant, 2003:319; 0osthuizen, 2010; s 61 of the Internal Revenue Code of the USA). In other words, the IRS, as a general rule, allows only the cost of winning bets as a deduction (Kee, 1995), with the result that losses from gambling are effectively ring-fenced (Blau, 2001; Oosthuizen, 2010). For professional gamblers, however, certain business expenses are deductible, provided that no assessed losses may be carried forward to subsequent years of assessment (Cnossen 2005, Oosthuizen, 2010).

In South Africa, a similar approach is followed. Proceeds from gambling activities are included in taxable income if the manner in which the proceeds were collected was 'routine or systematic' (Morrison v CIR, 1950 (2) SA 449 (A) (16 SATC 377)), irrespective of the legality of the gambling activity (Oosthuizen, 2010; Casino Enterprises (Pty) Ltd (Swaziland) v Gauteng Gambling Board and Others, [2011], All SA 305 (GNP)). Therefore, a professional gambler will be taxed on his/her winnings, similar to the tax treatment of business income (Koekemoer et al., 2013; De Koker \& Williams, 2011). If the gambling is merely for entertainment or as a hobby, the proceeds will be of a capital nature. In terms of the Eighth Schedule to the Act, these amounts will not be subject to CGT (Oosthuizen, 2010). More specifically, para 60 of the Eighth Schedule to the Act requires a natural person's capital gains and losses on gambling, carried out in terms of the country's relevant laws, to be disregarded. Table 1 summarises the tax consequences for professional and non-professional (or casual) gamblers in South Africa, the USA and Australia respectively.

TABLE 1: Key differences between the taxation of gambling winnings in South Africa, Australia and the USA

Professional Gamblers

Australia

USA

South Africa

Winnings included in Gross Income?

Costs allowed as a deduction against Gross Income?

Note 1

Casual gamblers 


\begin{tabular}{|c|c|c|c|c|}
\hline & Australia & USA & $\begin{array}{l}\text { South Africa } \\
\text { (currently) }\end{array}$ & $\begin{array}{l}\text { South Africa } \\
\text { (Proposed) }\end{array}$ \\
\hline Winnings included in Gross Income? & & Note 1 & & Note 2 \\
\hline $\begin{array}{l}\text { Costs allowed as a deduction against Gross } \\
\text { Income? }\end{array}$ & & Note 3 & & Note 4 \\
\hline
\end{tabular}

Source: Authors'analysis

Notes:

1. Limited to the $2 \%$ rule. This rule limits the deduction of gambling losses to a maximum of $2 \%$ of Adjusted Gross Income (gross gambling income less gambling related costs incurred).

2. Either $15 \%$ of the gross winning, subject to withholding tax or an additional $1 \%$ of the revenue levy? Further clarity is required.

3. Limited so as not to create an assessed gambling loss.

4. R25 000 once-off or annual deductions if withholding tax applied or none if turnover levy applied. - Further clarity is required.

To summarise, TABLE 1 shows that the taxation of professional gamblers in Australia, South African and USA is similar, with gains and losses generally taken into account when determining a taxpayer's taxable income. Currently, casual gamblers in South Africa and Australia do not have their gambling winnings included in gross income, and the associated costs are not allowed as a deduction for tax purposes. This is in contrast to the USA, where casual gambling does have tax implications, a situation which may apply in the future to South African casual gamblers.

\section{ADVANTAGES OF A TAX ON GAMBLING WINNINGS}

The proposed withholding tax or levy on gambling (the proposed Gambling Tax) has been defended on several grounds. Government is of the opinion that this offers a means of expanding the tax base, a key policy consideration given high levels of unemployment and growing state expenditure (Gordhan, 2011; 2012). In the context of a recessionary environment, the South African Revenue Service (SARS) would be able to collect additional revenues fairly (see Vivian, 2006, Gordhan, 2011). Where gambling constitutes a taxpayer's trade, incomes earned are, in substance, similar to those generated from other sources of employment (De Koker \& Williams, 2011) and ought to be subject to either normal tax or a levy to promote parity in the tax treatment of similar incomes (Kreiser \& Jowitt, 1993; Oosthuizen, 2010). Where winnings from gambling are capital in nature, the underlying gains can reasonably be subject to a withholding tax, because a tax on a windfall gain does not impose an undue burden on the taxpayer or amount to a form of double taxation given the current exemption of gambling winnings from capital gains tax in terms of para 60 of the Eighth Schedule to the Act, where it is stated that ' $a$ person must disregard a capital gain or capital loss determined in respect of a disposal relating to any form of gambling, game or competition' (Kreiser \& Jowitt, 1993; Vivian, 2006; 0osthuizen, 2010). Finally, from a social perspective, there is a well-documented correlation between excessive gambling and domestic violence, unsustainable individual debt and household poverty (Wheeler, Rigby \& Huriwai, 2006). The proposed withholding tax may indirectly tackle this by reducing the propensity for individuals to engage in gambling, similar to the rationale behind 'sin taxes' (Gordhan, 2011). Despite arguments in favour of the proposed gambling taxes, a number of key policy considerations should be taken into account. 


\section{UNINTENDED CONSEPUENCES OF THE PROPOSED TAXATION OF GAMBLING WINNINGS}

Unintended consequences may detract from the projected benefits of the proposed gambling taxes. For example, governments have historically regulated the extent to which, and the conditions under which, gambling is permitted. Governments also developed an early financial interest in legalising gambling, realising that certain forms of gambling were a productive tax base. The result is a conflict of interests, where governments attempt to regulate the industry to control excessive gambling while wanting to maintain an important source of tax revenue (Karcher, 1989; Smith, 1999).

There might well be a need for socially responsible gambling in South Africa (Gordhan, 2011: 32), but it is interesting to note that neither the 2011 nor 2012 budget speeches refers to the R200 billion contribution made by the gambling industry to Treasury during the 2009 financial year (Oosthuizen, 2010), the R140 billion that the casino industry has added to the Gross Domestic Product since gambling was legalised in 1996 (CASA, 2009), or the estimated R615 million added to the Gauteng provincial government's coffers (Oosthuizen, 2010; Ossa \& Vaillancourt, 2011). In this context, a possible reason for Treasury's hesitance to communicate clearly its intended tax reforms are the adverse implications for existing revenue collections at a time of economic uncertainty and global recession (Devaney \& Jacobs, 2009). With government under increasing pressure to improve service delivery (SA News Weekly, 2012), and to improve the plight of the poor (SA Government Report, 2008), the imposition of an additional tax could, ironically, reduce revenues and the ability of the state to offer social relief. This possibility is deemed to be highly problematic, especially given looming national and local elections in which government will try to sell itself as protector of the community as well as a contributor to the greater social welfare of the state. The proposed Gambling Tax might also have other stumbling blocks, each of which is discussed in more detail below.

\subsection{Allowing a deduction for gambling losses}

A detailed discussion on the provisions of the Act and exploring relevant case law such as Plate Glass and Shatterprufe Industries Finance Co (Pty) Ltd v SIR 1979 (3) SA 1124 (T), 41 SATC 103 at 108 and Port Elizabeth Electric Tramway Co Ltd v CIR 1936 CPD 241, 8 SATC 13 dealing with the deductibility of gambling losses under the current tax regime are beyond the scope of this paper. What is, however, relevant is that imposing a withholding tax on winnings could create an incentive for taxpayers to structure their gambling activities deliberately as a 'trade' to avoid the withholding tax and secure a deduction for losses. This is especially true given that most gamblers would be in a loss-making position (British Columbia Gaming Board, 2007). Although s20A(4) serves as an anti-abuse mechanism, it only ring-fences assessed losses and does not deny deduction of al/gambling costs, with the result that the costs of non-winning bets can still be offset against gambling winnings (Oosthuizen, 2010). Adding to this are the practical difficulties of applying and enforcing s20A. Does SARS, for example, have the manpower to audit each tax return where gambling costs, material for the taxpayer but inconsequential for Treasury, are incorrectly offset against non-gambling incomes? Related to this, how likely is the average taxpayer to apply correctly the relatively complex tax rules that deal with the demarcation of incomes from different sources and the ring-fencing of relevant expenditures? Concurrently, rather than encourage responsible gambling, the proposed tax structure could 
indirectly promote reckless wagering when taxpayers believe that their costs are deductible for tax purposes.

This is not to imply that denial of all gambling costs is a desired solution. For taxpayers to pay only quid pro quo for state services, expenses incurred in the production of taxable incomes ought to be allowed as a deduction for tax purposes (Smith; 1776; Vivian, 2006). The ringfencing provisions in operation in the USA and s20A of the Act are inconsistent with this (Blau, 2001:12, Oosthuizen, 2010). A clear tension exists between the argument that all income, irrespective of its nature, ought to be taxed, and the denial of deductions for certain expenditure in producing these 'homogeneous' income results. This detracts from the notions of justice, equity and legitimacy of the tax system (see, for example, Suchman, 1995; Vivian, 2006; Maroun et al., 2011). Rather than see the proposed gambling taxes as a material source of revenue which allows Treasury to finance state services and discourage excessive gambling, taxpayers may conclude that the state, as in the e-Toll saga (Mahlangu, 2013), is simply embarking on a campaign of stringent revenue collection irrespective of the principles of tax fairness (see Farra, 2011; Maroun et al., 2011).

\subsection{Subjecting gambling winnings to tax}

Important for tax policy is the need for taxpayers to be able to sustain themselves adequately while contributing fairly for state services (Smith, 1776; Vivian, 2006). Interconnected with this are principles of equity. Taxpayers in equal positions should have equal tax commitments (horizontal equity), while wealthier taxpayers ought to shoulder a larger tax load (vertical equity) (Vivian, 2006; Maroun et al., 2011). In order to achieve vertical equity, gambling winnings should be subject to a proportional tax rate (Oosthuizen, 2010), as argued by Vivian (2006) and Smith (1776), rather than the flat $15 \%$ withholding tax or $1 \%$ level proposed by Ghordan $(2011 ; 2012)$.

At the same time, the principle of horizontal equity would suggest that taxpayers enjoying comparable capital gains should find themselves in equivalent tax positions (Vivian, 2006; Kee, 1995). The casual gambler never intended to generate an income. He engaged in gambling for entertainment purposes, with the result that any gain is a windfall and ought to be exempt from income and capital taxes (Smith, 1776; Vivian, 2006), in precisely the same way that the disposal of a primary residence or personal use asset (Conda, 2006) is effectively tax-exempt (see Vivian, 2006; Rubner, 1996). In this way, the withholding tax imposed on amounts that would otherwise have gone untaxed is tantamount to an indirect tax charge, in contravention of horizontal equity (Kee, 1995). Concurrently the proposed withholding tax does not reflect the risk inherent in the underlying source of revenue. While an individual earning a higher salary is subject to a greater effective rate of taxation, the degree of uncertainty inherent in the generation of revenue is far less than it would be for the gambler who faces unfavourable odds at the casino (British Columbia Gaming Board, 2007). Finally, how will the effects of inflation be taken into account? Over time, the effect of the annual proposed exclusion (whether a R250000 or R50 000) will be eroded, rendering it inconsequential, similar to the arguments raised about the lack of inflation-linked annual exclusions and inclusion rates for CGT, which renders these exclusions insignificant over time (see Ededes, 2001, Maroun et al., 2011).

The above arguments highlight a number a complex and subjective issues. How should the South African government balance the need to discourage excessive gambling against the importance of horizontal and vertical equity for the credibility of the South African tax system? Where a taxpayer wins a large prize as a result of gambling, should the fact that the withholding tax will 
not amount to an undue net burden be given greater weight than the need for a proportionate tax rate that could lead to a larger tax charge at the expense of horizontal and vertical equity? Unfortunately, the most recent budget speeches give no indication that these matters have been contemplated by the legislature. The minister has only proposed a $15 \%$ withholding tax and/or $1 \%$ levy without any explanation of the rationale for this model of taxation.

\subsection{Tax levies as a source of double taxation}

The 2012 Budget Speech refers to a turnover levy on gambling as a means of increasing state revenue, but there is no indication that this might entail instituting a form of double taxation (see Kee, 1995; Oosthuizen, 2010). In terms of current South African legislation, Provincial Gambling Boards tax land-based casino operators. A fixed levy on turnover (akin to a licence fee) is charged to fund Gambling Boards and contribute to provincial coffers. The gambling industry, like any other, is also subject to normal income tax and VAT (Oosthuizen, 2010; De Koker and Williams, 2011). What the $1 \%$ levy therefore amounts to is the introduction of an additional cost for the industry - not allowed as a deduction for income tax purposes - which, in substance, increases the effective tax rate to above the $28 \%$ applicable to most other juristic persons.

\subsection{The question of efficiency}

Although limited information is available, it is commonly believed that taxation of gambling gains would adversely affect an individual's propensity to gamble, as gambling gain loses its attraction and appeal to the taxpayer, should he/she now need to pay tax on the winnings (Kreiser \& Jowitt, 1993). In a study conducted in the United Kingdom (UK), it was found that that the demand for bookmaker gambling is highly sensitive to taxation rates, and that the decline in the rate of taxation led to a significant increase in the demand for on-shore betting (Paton, Siegel \& Williams, 2003). As a result, there is no guarantee that the proposed gambling taxes, taking into account the tax-elasticity of demand in South Africa, will produce sufficient net revenues to cover the costs of the new system (Kreiser and Jowitt, 1993; Oosthuizen, 2010; Vorster, 2012). This is especially true given the opportunity costs of lower corporate socially responsible investment, VAT charges, and fewer employment opportunities in the gambling sector that could result from the imposition of additional taxes at a time of increasing economic uncertainty (Vorster, 2012). Detailed empirical work, which is beyond the scope of this research, is therefore needed to test the economic feasibility of the proposed gambling taxes before they are promulgated. Again, there is no indication that this has been done by Treasury.

\subsection{Possible administrative burdens}

In the USA, the withholding tax system is designed to mitigate the risk of taxpayers failing to declare gambling winnings. Only winnings over a certain amount are reported for tax purposes by the gambling house concerned (Oosthuizen, 2010). This system is, however, not without weaknesses. Reporting thresholds are sufficiently high to leave a significant number of winning bets untaxed. There is also speculation that some operators set pay-outs deliberately to avoid withholding taxes (Alarie and Igelman, 2007; Oosthuizen, 2010). Similar challenges may be relevant for SARS. Cognisance will also need to be taken of the added administrative costs, both on the part of the operator and SARS in the form of maintenance of sophisticated collection systems, and the need for adequate record-keeping by gambling houses and gamblers alike 
(Oosthuizen, 2010). This may be especially true for individual gamblers, where maintenance of detailed records is less likely, adding to the risk of undeclared winnings and incorrect deductions of expenditure, similar to the problems encountered when introducing the CGT system (Meyerowitz, Emsile \& Davis, 2007; Maroun et al., 2011).

\section{CONCLUSION}

This article has provided an exploratory account of the proposed withholding tax on gambling winnings and turnover levy for the industry recently proposed by government. While there may be several advantages associated with additional gambling-specific taxes, Treasury appears to have overlooked a number of significant challenges, whether due to inadequate planning or from a lack of clear policy direction regarding the taxation of the gambling industry.

Firstly, the nature and extent of deductions available for costs incurred in the production of gambling incomes need to strike a balance between equitable and consistent application of existing legislation with curtailment of excessive gambling. Interconnected with this is the need to moderate the drive for increasing state revenue, given the importance of the perceived fairness of the proposed tax system for it to be regarded as a legitimate means of widening the tax base. The withholding tax on gambling may not amount to an undue burden on taxpayers due to gains being regarded as windfalls. The counter-argument is that that the proposed flat rate (and 'exclusion' of either R25000 or R50 000) is less desirable than a proportionate one and fails to make adjustments for the effects of inflation and the risk profile of taxable gains. It may also lead to the taxation of amounts that would have attracted neither income nor Capital Gains Tax, despite the economic substance of these winnings being similar to other gains presently exempt from tax.

Of equal concern is the fact that the proposed levy amounts to a form of double taxation. The gaming industry is currently subject to income tax and a provincial levy akin to a licensing charge. Consequently, a $1 \%$ charge on turnover has the same effect as an increase in the effective tax rate for gaming companies, while most juristic persons pay corporate tax at $28 \%$. This could put pressure on industry profitability, leading to a situation where the increase in revenues from the gambling tax is more than offset by the loss in normal tax and VAT. Together with the opportunity costs of reduced corporate social spending and potential job losses, the economic feasibility of the proposed gambling taxes is not certain, something which needs to be carefully considered before the tax is introduced. As part of this assessment, government also needs to take into account the administrative burden of the proposed taxes and whether or not it will be able to implement and enforce the withholding tax, the levy or both.

To this end, Treasury needs to carry out a careful evaluation of the costs and benefits of the proposed taxes, a process which should be transparent and open to public commentary. Ultimately, what the minister of finance must remember is that 'taxation is an art, a technique, as well as a science and it always needs to be judged against the conditions of time and place' (Groves 1974:24). In the interim, South Africa may want to leave the tax legislation on gambling winnings as is, until more thorough research on a number of socio-economic issues associated with changing tax laws has been completed.

In reaching this conclusion, it must be noted that this study is not without limitations. It concentrates in an exploratory fashion only on the proposed gambling tax in South Africa to inform the on-going debate. Future research needs to expand on this by examining the 
advantages and disadvantages of equivalent taxes in other jurisdictions. In addition, this article has not carried out a detailed empirical analysis. Given the lack of formal literature on gambling tax in South Africa, a qualitative study was best suited to offering initial insights. Subsequent work may expand on this in a positivist setting - for example, by creating a model to predict future costs and revenues or changes in effective rates after the introduction of the tax.

\section{LIST OF REFERENCES}

Ahrens, T. et al. (2008). The future of interpretive accounting research - A polyphonic debate. Critical Perspectives on Accounting, 19, pp. 840-866.

Alarie, B. \& Igelman, A. (2007). Bet on it: the taxation of online gambling. Taxation and Valuation of Technology, [Online] available: http://papers.ssrn.com/sol3/papers.cfm?abstract_id=1025588. (Accessed 2 October 2011)

Australian Income Tax Assessment Act 38 of 1997

Auten, G. \& Cordes, P. (1991). Policy watch: cutting capital gains taxes. Journal of Economic Perspective, 5(1), pp. 181-192

Blau, C.W. \& Coutant, J.B. (2003). Federal tax treatment of gains and losses from gambling transactions. Gaming Law Review, 7(5), pp. 319-322. [Online] available: http://www.liebertonline.com. (Accessed 19 0ctober 2011)

Blau, C.W. (2001). Tax treatment of gambling: the pros and cons. Gaming Law Review, 5(1), pp. 11-24. [Online] available: http://www.liebertonline.com (Accessed 21 December 2011)

Botten, N. (2009). Management Accounting Business Strategy. Oxford: CIMA Publishing.

British Columbia Gaming Board. (2007). [Online] availble:

http://www.bcresponsiblegambling.ca/other/odds.html (Accessed 6 November 2011)

Bronson, S. N., Hogan, C. E., Johnson, M. F. \& Ramesh, K. (2011). The unintended consequences of PCAOB auditing Standard Nos. 2 and 3 on the reliability of preliminary earnings releases. Journal of Accounting and Economics, 51, pp. 95-114.

Casino Association of South Africa (CASA). (2009). Economic impact of casinos since the legalisation of gambling in South Africa. CASA Newsletter, 17(October):1-4. [Online] Available:

http://www.casasa.org.za/. (Accessed 19 November 2011).

Casino Enterprises (Pty) Ltd (Swaziland) v Gauteng Gambling Board and Others, [2011], All SA 305

Cnossen, S. (2005). Theory and Practise of Excise Taxation. London: Oxford University Press.

Conda, C. (2006). The best cap-gains tax rate is zero. [Online] available:

http://freedomworks.org/informed/issues_template.php?issue_id=2554. (Accessed 19 November 2011)

Creswell, J.W. (2009). Research Design: Qualitative, Quantitative, and Mixed Methods Approaches, $3^{\text {t }}$ edition. London: Sage Publications.

De Koker, A.P. \& Williams, R.C. (2011). Silke on South African Income Tax, Memorial edition. Durban: LexisNexis. 


\section{Segal \& Maroun}

De Jager, P., Parsons, S. \& Roeleveld, J. (2013). A Commentary on SARS' Proposed Fair Value Tax on Financial Instruments. SA Journal of Accounting Research, 26(1) No. 1, 2013. pp.1-2.

Deutsch, R.L., Freizer, M.L., Fullerton, I.G., Gibson, M.M., Hanley, P.J. \& Snape, T.J. (2005). Australian tax handbook. Sydney: Thompson ATP.

Devaney, M. \& Jacobs P. (2009). Online gambling and international regulation: an outside bet. Information \& Communications Technology Law, 18(3), pp. 273-283.

Drury, C. (2005). Management and Cost Accounting. London: Thomson Learning.

Ededes, J. (2000) Capital Gains Tax, Financial Mail, 15 April, pp. 1-2.

Farrar, J. (2011). Tax fairness in Canadian government budgets: How fair is fair? Critical Perspectives on Accounting, 22(4), pp. 365-375.

Gordhan, P. (2011). Budget Speech 2011. [Online] Available:

http://www.treasury.gov.za/documents/national\%20budget/2011/speech/speech2011.pdf

(Accessed 18 April 2011).

Gordhan, P. (2012). Budget Speech 2012. [Online] available:

http://www.treasury.gov.za/documents/national\%20budget/2012/speech/speech.pdf (Accessed 16 September 2012).

Groves, H.M \& Curran, D.J. (eds.) (1974), Tax Philosophers. University of Wisconsin Press, Wisconsin.

Humphrey, C. (2008). Auditing research: a review across the disciplinary divide. Accounting, Auditing \& Accountability Journal, 21(2), pp. 170-203.

Humphrey, C., Kausar, A., Loft, A. \& Woods, M. (2011). Regulating Audit beyond the Crisis: A Critical Discussion of the $\varepsilon U$ Green Paper. European Accounting Review, 20(3), pp. 431-457.

Income Tax Act 58 of 1962 .

Karcher, A. (1989). Lotteries. California: Transaction Publishers.

Kee, P.T. (1995). Should gambling gains be taxed as income? Murdoch University Electricity Journal of Law, 2. [Online] Available: http://www3.austlii.edu.au/au/journals/MurUEJL/1995/22.html.

(Accessed 8 July 2011).

Koekemoer, A., Wilcocks, J.S., van Schalkwyk, I., Stiglingh, M. \& de Swardt, R.D.

Silke: South African Income Tax 2013 edition: LexisNexis 2013.

Kreiser, L. \& Jowitt, દ. (1993). The taxation of gambling winnings in Australia and the United States: a comparative study. The International Tax Journal, 19(3), pp. 75-82.

Mahlangu, S. (2013). E Toll - A test of South Africa's Attitude towards the Rule of Law. Business Day, 18 February, [Online] Available: http://www.bdlive.co.za/opinion/2013/02/18/e-toll-a-test-ofsouth-africas-attitude-towards-the-rule-of-law (Accessed 5 July 2013).

Maroun, W., Turner M.\& Sartorius K. (2011). Does Capital Gains Tax Add To Or Detract From the Fairness of The South African Tax System? South African Journal of Economic and Management Sciences, 14(4), pp. 436-448.

Marriott L. Power and ideas: the development of retirement savings taxation in Australasia. Critical Perspectives on Accounting 2010; 21(7), pp. 597-610.

Meyerowitz D., Emsile T. \& Davis, D. (2001) Capital Gains Tax, The Taxpayer, 50(4). 
Minarik, J. (1981), Capita/ Gains Tax, $5^{\text {th }}$ Edition. Washington: Brookings Institution.

Morrison v CIR, 1950 (2) SA 449 (A), 16 SATC 377.

National Gambling Act 7 of 2004.

Olivier, L. (2007). Determining a taxable capital gain or assessed capital loss: some problems, Meditari Accountancy Research, 15(1), pp. 35-50.

Oosthuizen, W.J. (2010), A comparative study between South Africa, the United States and Australia of the taxing of income from gambling activities, MCom dissertation. Pretoria: University of Pretoria, Pretoria. [Online] Available: http://upetd.up.ac.za/thesis/available/etd-07202011-133953/ $>$ >1l/445/gm (Accessed 21 September 2011).

Ossa, R. \& Vaillancourt, F. (2011). The Taxation of Gambling in Africa, Georgia State University,[Online] Available: http://aysps.gsu.edu/isp/newsletter/201l/may/index.html. (Accessed 11 November 2011).

Paton, D., Siegel, D. \& Williams, L. (2003). Taxation and the Demand for Gambling: New Evidence from the United Kingdom Rensselaer: Working Papers in Economics, [Online] Available: http://www.nottingham.ac.uk/business/LIZDP_Publications.html (Accessed 11 November 2011).

Paulsen, N. (2013). Budget Alert 2013, Cliffe Dekker Hofmeyer, [Online] Available: http://www.cliffedekkerhofmeyr.com/export/sites/cdh/en/news/publications/2013/tax/downloads /Budget-Alert-2013.pdf (Accessed 27 May 2013).

Public Company Accounting Oversight Board (PCAOB). (2007). Report on the Second-year Implementation of Auditing Standard No. 2: An Audit of Internal Control over Financial Reporting Performed in Conjunction with an Audit of Financial Statements [Online]. Washington, DC: PCAOB. [Online] Available: http://pcaobus.org/Inspections/Documents/2006_03-21_Release_104-2006078.pdf (Accessed l September 2012).

Plate Glass and Shatterprufe Industries Finance Co (Pty) Ltd v SIR 1979 (3) SA 1124 (T), 41 SATC 103 at 108 .

Roberts, S. (2006). Capital gains tax: advantages \& disadvantages of capital gains tax cut. India Finance and Investment Guide, July. [Online] Available:

http://finance.indiamart.com/taxation/advantages_disadvantages_capitalgains.html (Accessed 5 June 2013).

Rubner, A. (1966). The Economics of Gambling. London: Macmillan.

SA News Report, (2008). South African Government News Agency. Towards an Anti- Poverty Strategy for SA - Discussion Document [Online] available:

http://www.info.gov.za/view/DownloadFileAction?id=92543. (Accessed 5 June 2013).

SA News Report, (2012). South African Government News Agency. Embrace Innovation to Improve Service Delivery: Kiviet. [Online] Available: http://www.sanews.gov.za/south-africa/embraceinnovation-improve-service-delivery-kiviet (Accessed 5 June 2013).

Sikka, P. \& Willmott, H. (2010). The dark side of transfer pricing: Its role in tax avoidance and wealth retentiveness. Critical Perspectives on Accounting, 21(4), pp. 342-356.

Smith, A. (1776). An Inquiry into the Nature and Causes of the Wealth of Nations, 1976 edn, 0xford: Clarendon Press.

Smith, B.W. (2002). Gaming law: unfair tax treatment of gaming professionals. Gaming Law Review, 6(5), pp. 445-449. 


\section{Segal \& Maroun}

Smith, J.P. (1999). Australian Gambling Taxation. Economics Program, Research School of Social Sciences, Australian National University, Discussion Paper no 42.

Sarbanes-0xley Act of 2002 (SOX). Pub. L. 107-204, 116 Stat. 745. SOX. United States of America. Suchman, M. (1995). Managing Legitimacy: Strategic and Institutional Approaches. Academy of Management Review, 20(3), pp. 571-610.

Vakkur, N. V., Mcaffee, R. P. \& Kipperman, F. (2010). The unintended effects of the Sarbanes-0xley Act of 2002. Research in Accounting Regulation, 22(1), pp. 18-28.

Venter, J. \& de Clerq, B. (2007). Tax compliance burden for small, medium and micro establishments in the businesses services industry. South African Journal of Economic and Management Sciences, 10(1), pp. 33-53.

Vivian, RW. (2006). Equality and personal income tax: the classical economist and the Katz Commission, South African Journal of Economics, 74(1), pp. 79-109.

Voster, D. (2000). Capital gains tax: a discredited tax. Tax planning, 14(6).

Vorster, N. (2012). Betting on the Future - South African Gaming Outlook 2012 - 2016, Price Waterhouse Coopers, [Online] Available: http://www.pwc.co.za/en_ZA/za/assets/pdf/gamingoutlook-2012-south-africa.pdf (Accessed 28 May 2013).

Wheeler, B., Rigby, J. \& Huriwai, T. (2006). Pokies and poverty: problem gambling risk factor geography in New Zealand, Health \& Place, 12(1), pp. 86-96.

Woellner, R., Barkoczy, S., Murphy, S., Evans, C. \& Murphy, S. (2011). Australia: Australian Taxation Law: CCH Australia. 